Document downloaded from:

http://hdl.handle.net/10251/63679

This paper must be cited as:

Aragonés-Beltrán, P. (2015). Measuring economic sustainability of energy use: an ANPbased evaluation of some European Union countries and Turkey. International Journal of Management and Decision Making. 14(3):205-223. doi:10.1504/IJMDM.2015.070759.

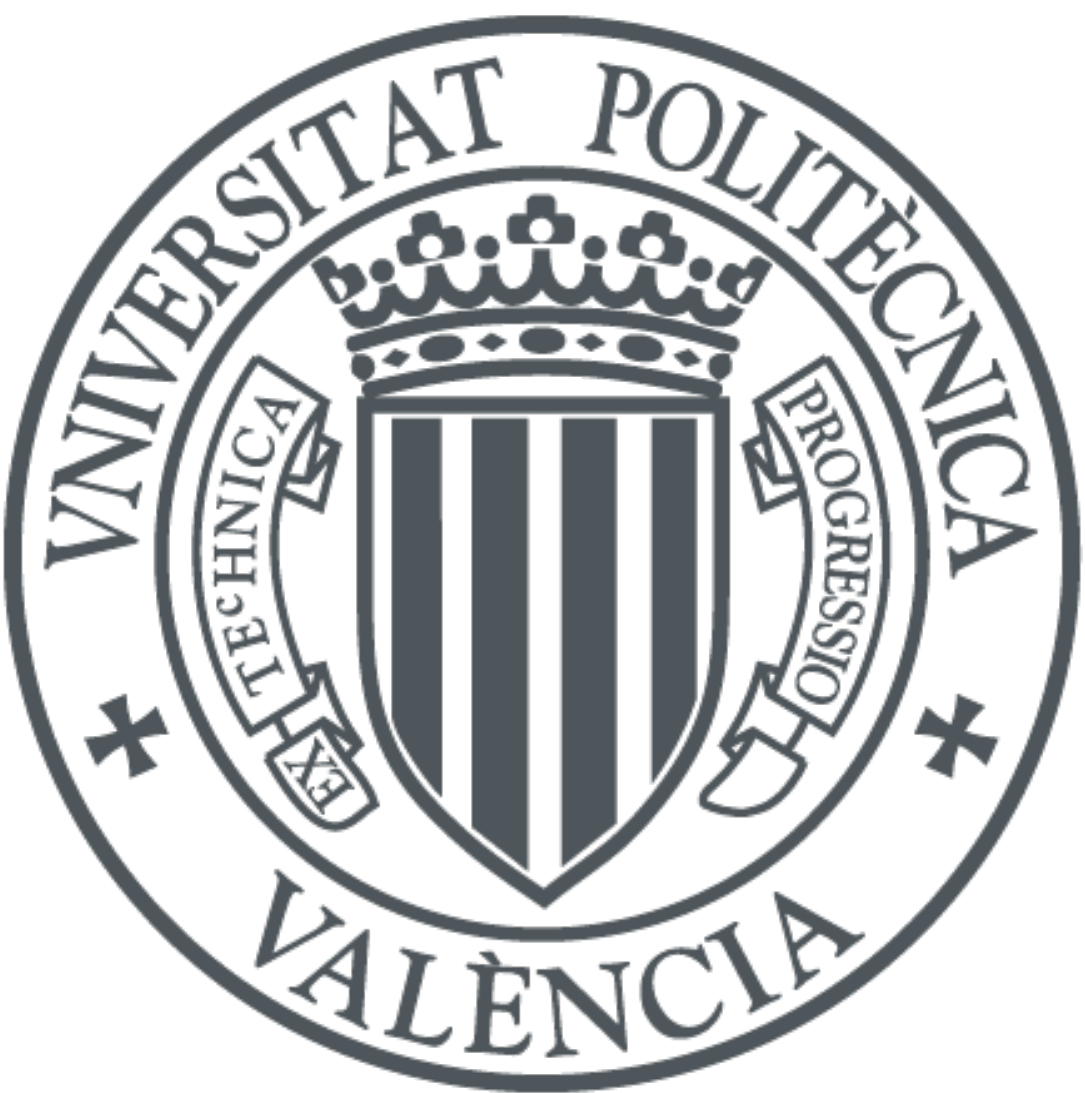

The final publication is available at

http://dx.doi.org/10.1504/IJMDM.2015.070759

Copyright Inderscience

Additional Information 
Measuring economic sustainability of energy use: an ANP-based evaluation of some European Union countries and Turkey

Authors: Aylin Çiğdem Köne ${ }^{1}$, Mónica García-Melón ${ }^{2}$, Pablo Aragonés-Beltrán ${ }^{3}$ Tayfun Büke ${ }^{4}$

Address:

${ }^{1}$ Department of Economics, Muğla Sitkı Koçman University, 48000 Muğla, Turkey ${ }^{2}$ INGENIO (CSIC-UPV), Universitat Politècnica de Valencia, Camino de Vera s/n, 46022 Valencia, Spain

${ }^{3}$ INGENIO (CSIC-UPV), Universitat Politècnica de Valencia, Camino de Vera s/n, 46022 Valencia, Spain

${ }^{4}$ Department of Energy Systems Engineering, Muğla Sitkı Koçman University, 48000 Muğla, Turkey

\section{Email:}

1ckone@mu.edu.tr

2 mgarciam@dpi.upv.es

3 aragones@dpi.upv.es

${ }^{4}$ tbuke@mu.edu.tr

\section{Biographical notes:}


Aylin Çĭğdem Köne is professor of Economics at Muğla Sitkı Koçman University.

Her research focuses on sustainable development indicators, performance evaluation, and integrated assessment in local or national contexts

Mónica García-Melón is profesor of Engineering Projects and Multicriteria Decision Techniques at Universitat Politècnica de València. Her research lines are focused on the applications of MCDA to Sustainability.

Pablo Aragonés-Beltrán is professor of Project Management and Multicriteria Decision Techniques at Universitat Politècnica de València. His research lines are focused on the applications of MCDA to Project Management.

Tayfun Büke is professor at the Energy Systems Engineering Department of Muğla Sitkı Koçman University. He teaches courses on energy systems engineering, numerical methods for engineers, nuclear reactor engineering. His research has emphasis on environmental effects of power plants, sustainable energy development, and comparison of energy systems. 


\title{
Measuring economic sustainability of energy use: an ANP-based evaluation of some European Union countries and Turkey
}

\begin{abstract}
This paper presents a new methodology for evaluating the economic sustainability of countries' energy systems. The aim of the work is to improve the support tools for policy makers as the scale and complexity of the global energy industry demands a country-by-country approach to managing change. The proposed participatory Analytic Network Process model was applied to the five largest energy consumers in the European Union, namely France, Germany, Italy, Spain and the United Kingdom plus Turkey -a candidate for the European Union. The criteria used for the evaluations were selected from the economic dimension of the Energy Indicators for Sustainable Development. Results show that the best performer country is the United Kingdom followed by France, Turkey, Germany, Spain and Italy. Finally we want to highlight that the methodology is able to grant participated decisions through a multiexpert traceable and transparent assessment process.
\end{abstract}

Keywords: sustainable energy development; economic sustainability; European Union; Turkey; energy systems; energy indicators; energy security; end-use patterns; energy policy evaluation; analytic network process; multi-criteria decision analysis; multi-expert decision analysis; energy experts; expert judgments; criteria weighting. 


\section{Introduction}

Evolving from the European Coal and Steel Community, the European Union (EU) has identified energy as one of its priorities. Although energy policy has always been a matter of paramount importance to the EU, its focus has shifted and evolved over the past 50 years (Eurostat, 2009). Initially energy policies concentrated on the creation of a single market in coal and cooperation in the field of nuclear energy. However the oil crisis of the 1970s showed the need for coordinated actions to ensure security and diversity of supply. Since then the issues of energy saving, energy efficiency, renewables, prices and competitiveness and integration of energy markets have been agreed at Community level. Today the main EU directives and other policies target sustainable energy development (EC, 2014a; 2014b). The main goal of the EU's energy strategy is to transform the current energy system in order to achieve a secure, competitive and decarbonised energy system.

A repeating element that runs through much of the EU energy policy discussion is the lack of competence. The EU and its institutions can only play a coordinating role while the competence and authority in this field remains at the member state level. After all, member states want to keep control over their national energy policies. Besides, the different structures of national energy sectors and the conflicting interests of producer and non-producer countries restrict the creation of a common energy policy. Even though the European Commission's Energy Roadmap 2050 suggests a greater scope of governance for the EU, the European treaties still reserve the member states the decisive role in shaping the energy mix (Fischer and Geden, 2012). 
Given the diversity of energy policies in Europe, this paper aims to measure economic sustainability of energy use in several European countries and rank them according to their sustainability performance using an Analytic Network Process model. The proposed model builds on the economic dimension of the Energy Indicators for Sustainability Development (EISD). In fact, there are many similarities between the priorities of the EU energy strategy and the EISD methodology.

\section{Energy indicators for sustainable development}

The term 'sustainable development' was popularised by the World Commission on Environment and Development (WCED) in its 1987 report entitled Our Common Future (WCED, 1987). Since then, the term has become an integral part of political and scientific discourse. In fact, the concept is widely accepted and sustainable development has been adopted as a desirable goal by governments, business and international institutions. However, although the concept has a deep impact on shaping the international agenda and the international community's attitude towards environmental, economic and social development, the term sustainable development suffers from definitional ambiguity or vagueness (IPCC, 2007). Various stakeholders give the term different meanings, which has led to confusion and compromised implementation (Drexhage and Murphy, 2010). To deal with the ambiguous character of sustainable development, great effort has been devoted to developing quantitative indicators (Parris and Kates, 2003). The emphasis on sustainability indicators is motivated by several factors, such as decision making and management, advocacy, participation and consensus building, and research and analysis. 
The search for appropriate indicators of sustainable development has been going on ever since the Rio Conference. Agenda 21 adopted at the Rio Conference, in chapter 40, specifically calls on countries and international governmental and nongovernmental organisations to develop the concept of indicators of sustainable development and to harmonise them at national, regional and global levels (UN, 1992). The United Nations Commission on Sustainable Development took the lead in designing a set of sustainable development indicators several years ago, which has been followed by OECD and more recently, by the European Commission. There is a general consensus on the fact that it is impossible to define only a single indicator of sustainable development, and that a substantial number of indicators are necessary to capture all the important aspects of sustainable development in a particular application (Bossel, 2001). Therefore, sustainable development indicators integrate well known measures of economic growth (i.e. real gross domestic product) with several measures of social and environmental variables.

There is an inextricable link between energy and sustainable development. In view of the importance of energy for sustainable development, the International Atomic Energy Agency (IAEA) initiated the "Indicators for Sustainable Energy Development" project in 1999 in cooperation with various international organisations, including the International Energy Agency (IEA), UN Department of Economic and Social Affairs (UNDESA), and some Member States of the IAEA. The name of the project was later modified to EISD to refer to the broader spectrum of energy choices (IAEA, 2005). The main concern that lies behind the EISD is to address the most important energy-related issues of interest to countries worldwide. The most critical ones appear to be the environmental impact of energy-related activities -where climate change is of overriding concern-, access to lasting, 
dependable and affordable energy sources, and the differences in energy consumption among nations and individuals throughout the world, with nearly one fifth of the world's population still without access to electricity (IEA, 2011).

The EISD indicators comprise a wide range of energy indicators that are relevant for sustainable development and that are organised following the conceptual framework used by the United Nations Commission on Sustainable Development. The interagency report (IAEA, 2005) identifies and describes 30 EISD and provides guidelines and specific methodologies on how to construct them. The scheme of the EISD is presented in Figure 1.

As can be seen from Figure 1 the indicators are classified according to the three major dimensions of sustainable development: social (4 indicators), economic (16 indicators) and environmental (10 indicators). These are further classified by subthemes. Most of the indicators fall into the economic dimension, although some also address the environmental consequences (emissions) of energy production and use. Before their publication, the EISD were tested as a part of the IAEA project using country case studies - namely Brazil, Cuba, Mexico, Russia and Thailand. The results of these case studies were published in a special edition of the UN Natural Resources Forum journal (Abdalla, 2005). Country assessments (Rasmussen, 2003; Angelis-Dimakis et al., 2012; Ansari, 2012; Schlör et.al., 2013) or the assessment of sustainability of energy options (Jovanovic et al., 2011) assessing how the fuel mix is optimised in terms of sustainable energy systems goals (Bishop et al., 2008) are some examples of the EISD applications. It has been shown through these various studies that by being a standardised set of metrics, EISD can help to determine to what extent countries are properly responding to the new energy challenges. 


\section{Building the ANP model}

It is important for policymakers to set their policies with data-driven approaches. Here the major problem lies behind complexity of sustainability concept. Thus, current situations of the selected countries have to be identified and discussed with one value with the help of data sets. Although there are various sustainability assessment methodologies, models and tools developed so far, the certain characteristics of the Analytic Hierarchy Process (AHP) and the Analytic Network Process (ANP) make it useful tool for sustainability assessment and decision-making. Consequently, these two well-known techniques have been used in sustainability field (Köne and Büke, 2007; Wolfslehner and Vacik, 2008; Xiaodan et al., 2010; Atmaca and Basar 2012). The proposed model is structured around the key aim of the study, which is assessing economic sustainability of energy use. In order to build the model, the following questions must be addressed:

(i) Which are the alternatives to be ranked?

(ii) How are the experts selected?

(iii) What are the criteria to be considered for assessing energy systems?

(iv) How are the criteria grouped into clusters?

(v) What are the interdependences among the criteria?

(vi) Are there any dependencies among the alternatives?

(vii) What are the weights of the criteria?

(viii) How do the alternatives compare to each other with respect to the evaluation criteria? 
The methodology followed in the study was divided into three phases: problem analysis, synthesis and evaluation (see Fig. 2).

\subsection{Phase of problem analysis}

The first step in constructing the network involves identifying the alternatives. Although the aim of this study is to analyse European countries' energy systems in terms of their economic sustainability, when the number of alternatives to be assessed is very high (more than 7) or when the alternatives are heterogeneous, some measurement problems may arise (Giner-Santonja et al., 2012). Therefore, it is necessary to set some selection standards in order to ensure comparability between the alternatives. When evaluating energy systems, the size of the country, the number of inhabitants, population density or climate can be considered as relevant factors. For the present study, population was used as a selection standard. The countries with a population of more than 40 million inhabitants- France, Germany, Italy, Spain, Turkey and the United Kingdom- were chosen as the alternatives. Thus, both rules -maximum number of alternatives and working with a homogenous group- are satisfied. Besides, since these countries are the largest energy consumers in the European Union and its candidate countries (Eurostat, 2014), the alternatives represent a meaningful sample for our study.

In this work the whole process has been supported by experts. Five Turkish energy experts contributed to the study. They are all qualified experts in sustainable energy use, as well as in global energy issues. They work for different institutions like World Energy Council-Turkish National Committee, Turkish Atomic Energy Authority, The Scientific and Technological Research Council of Turkey-Marmara 
Research Centre, Istanbul Technical University-Energy Institute, Republic of Turkey Energy Market Regulatory Authority. All experts have $\mathrm{PhD}$ degree and three of them are university professors.

Evaluating the economic sustainability of energy systems requires dealing with several indicators. The indicators employed in this study are taken or modified from the EISD. As mentioned before, the EISD were developed by an interagency expert group from different organizations. As a result, the indicators reflect the expertise of these various agencies, recognised worldwide as leaders in energy and environmental statistics and analysis. Although the EISD are suitable for use as criteria, our experts suggested some modifications. The economic dimension of the EISD consists of 16 indicators (see Fig. 1). The experts eliminated some of these indicators for the purpose of the present study and finally selected seven indicators: overall energy use, overall energy productivity, fossil fuel share in energy use, non-carbon energy share in energy use, energy prices, energy imports and strategic fuel stocks. The initial and final list of indicators/criteria is presented in Table 1 . The data used in this study come from IEA (2006, 2007, 2008a, 2008b, 2009a, 2009b, 2010a, 2010b, 2011a, 2011b, 2011c, 2012a, 2012b) Eurostat (2012) and World Bank (2012) sources.

\subsection{Phase of data synthesis}

The EISD methodology provides valuable information about grouping the indicators (see Fig. 1 and Table 1). The economic dimension of the EISD is classified into two themes: Use and production patterns and security. In the present study, the expert team adapted this classification and the first cluster was named "use patterns" since our scope is limited to energy use patterns. 
In order to transfer the complexity of the real-world to the model, the determination of the influence network is crucial. Generally, experts identify the influences between the elements (alternatives and criteria) of the network based on their knowledge and experience. However, since EISD methodology sheets define the links between the criteria (IAEA, 2005), the experts were asked if they agreed with these links. Following their approval, the next step consisted of defining the influences among the alternatives.

For the determination of the influences between the elements of the network a zeroone interfactorial dominance matrix (Saaty, 1996) is used whose elements $a_{i j}$ take the value 1 or 0 depending on whether there is or there is not some influence of element $i$ on element $\mathrm{j}$. The rows and columns of the matrix are formed by all the elements of the network. The interfactorial dominance matrix is given in Table 2. Once the interfactorial dominance matrix is built, Fig. 3 is drawn in order to get a visual representation of the clusters.

With the aim of building the unweighted supermatrix, priorities are assigned to related elements and clusters. To this end, a questionnaire is designed using paired questions for the comparison analysis. Table 3 shows a sample questionnaire used for cluster comparisons.

Since in this study we consult five experts, a mathematical aggregation is needed. There are two synthesising methods to aggregate evaluations of experts: The geometric mean method and the weighted arithmetic mean method (Ishizaka and Labib, 2011). We used the geometric mean method in order to preserve the reciprocal property. Table 4 and 5 show the examples of pairwise comparisons for clusters and criteria and also the geometric means of them. 
The comparisons of the alternatives with respect to the evaluation criteria are done by using quantitative data. Instead of a single year data, the average values for the period 2000-2010 were used. The quantitative data are presented in Table 6. All calculations are performed with the help of Super Decisions software v. 2.2.2. Once the calculations are completed the unweighted supermatrix is built. By raising the weighted supermatrix (Table 7) to limiting powers until the weights converge and remain stable the limit supermatrix is achieved. The values of this limit supermatrix indicate the contribution of the alternatives to the goal.

The consistency of the judgments is very important in ANP as it is in all the scientific research. The Super Decisions software calculates inconsistency ratio for every pairwise comparison matrix. In order for a comparison matrix to be consistent, the inconsistency ratio must be less than 0.10 (Saaty, 1996, 1999). In fact, our study reports very low inconsistency ratios of $0.00000-0.07069$, which are better than the recommended $10 \%$ acceptable margin.

During the process of alternatives evaluation the experts were also asked to give their judgments on the weighting of the three clusters. Each value in a matrix cell indicates the weight assigned to that specific cluster obtaining the cluster matrix shown in Table 8. As can be observed, the use-patterns cluster exerts equal influence upon both the security and alternatives clusters while the security cluster exerts greater influence upon the alternatives cluster than upon the use-patterns cluster.

\section{Discussion of results}

Figure 4 shows the weights of each criterion. The weights obtained reflect the inherent importance that the experts give to each criterion. According to the results, C21 "energy imports" is the most important criterion with a weight of $42.12 \%$, while 
C13 "fossil fuel share in energy" has the lowest weight value (2.65\%). The priorities of the six alternatives regarding each cluster are presented in Figure 5. As seen from the figure, France and the United Kingdom hold the top rankings in the $\mathrm{C} 1$ "use patterns" and C2 "security" clusters respectively; while Italy holds the bottom ranking for both clusters.

Overall priorities for the alternatives can be seen in Figure 6. The results reflect the status of the country relatively to others in terms of economic sustainability of energy use. According to the results, United Kingdom is the best performer followed by France, Turkey, Germany and Spain. Italy has the least economically sustainable energy system.

The economic sustainability of a country's energy system is a function of two factors: use patterns and security which, in turn, are greatly affected by the country's resource endowment and policy decisions. Although all the alternatives are net energy importers, the United Kingdom is relatively less dependent on import resources and its top performance comes from its relatively high energy independence and high strategic fuel stocks. With the highest energy dependence Italy is ranked sixth. It should be noted that France, which obtains three-quarters of its electricity from nuclear power plants, has benefited significantly from nuclear technology to secure its energy independence. Due to the relative independence on import resources, France obtained the second place in the ranking.

In a general sense, geography, natural resources, population, and other natural factors along with policy choices determine the performance of a country. Although national resources and wealth contribute to energy performance they are not the dominating factors. According to the World Energy Council (WEC, 2011) policy choice is a key 
discriminating factor of energy performance. Therefore, the results can be read as the policy achievements of the countries.

The long life of a good deal of energy infrastructure means that an energy supply system changes only very slowly. Therefore, when the assumptions of the model are kept, the ranking will not change significantly in the short term. This heightens the need for governments to establish a clear, long-term policy framework - one that, while favouring sustainable investments, allows industry to plan for the future.

\section{Policy conclusions}

Energy policy affects all aspects of our lives from issues of national concern like national security, economic development and sustainability, to energy effects on our health. Therefore, energy policymaking has to accommodate multiple agendas:

economic growth, social welfare, environmental protection and national security. As a result, policy approaches to the national primary energy mix, infrastructure investment and market operation need to be governed by long-term energy sustainability principles.

Achieving sustainable energy requires regular monitoring of the impacts of selected policies and strategies to see if they are furthering sustainable development or if they should be adjusted. It is important to measure a country's state of energy sustainability and to monitor its progress or lack of progress towards sustainability. The main reasons for measurement can be listed as follows: First, policymakers need to know their country's current status concerning energy sustainability, what needs to be improved and how these improvements can be achieved. Second, it is important for policymakers to understand the implications of selected energy, 
programmes, policies and plans, and their impacts on development. Third, inevitably there will be trade-offs. Business and consumers need to understand the trade-offs that may be involved in adopting certain policies.

This paper presents a new approach to compare the energy systems by means of the ANP method based on energy experts' judgments. By the capacity of combining several sustainability indicators and reflecting the complexity of the real-world ANP can contribute to measurement of the policy efficacy. The ANP's quantitative approach allows policymakers a comparative understanding of energy performance relative to other countries.

The study is based on an empirical analysis of a range of indicators that reflect the economic dimension of sustainable energy. Focusing on the economic dimension of sustainability the proposed model compares the energy systems of six European countries. The comparison criteria are selected from the economic dimension of the EISD and modified by the experts. These indicators are selected based on high degree of relevance to the research goal and data for these indicators can be derived from reputable sources.

The model operates with seven criteria which have been grouped into two clusters. The end use patterns cluster contains overall energy use, overall energy productivity, fossil fuel share in energy use, non-carbon energy share in energy use and energy prices criteria while the security cluster contains energy imports and strategic fuel stocks. In short, the model ranks countries according to energy use and security and thereby highlights current challenges related to sustainable energy use. The model captures and aggregates country data to outline the relative energy performances of the selected countries by incorporating country data into a single value. The analysis 
of the results obtained with the model allows policymakers to observe the influences of the elements and also the significance order of the criteria.

In assessing the energy performance of countries across a number of key indicators the indicators are generally given equal priority and weighting, since there is no uniformly agreed methodology exists to weight individual indicators before aggregating them into a single value. Weights usually have an important impact on the resulting ranking especially whenever higher weight is assigned to indicators on which some countries excel or fail. Weights are essentially value judgments and have the property to make explicit the objectives underlying the construction of an assessment tool. Our study differs from the other studies in sustainable energy field since a participatory approach which involves expert judgement is used for the determination of the weights.

The properties of the proposed model make it a good candidate for a policy making tool and shows the following benefits for policy development:

- The model can be easily adapted to other countries. Thus, the paper provides a good approach for future research and for comparative analysis among different alternatives.

- The study could apply on the other two dimensions of sustainable energy which are societal and environmental sustainability. As future work we suggest to develop an ANP-based network model to compare the energy systems of selected countries using the environmental indicators specified in the EISD.

- Expert judgments express the relative importance of the indicators from the societal viewpoint. Therefore our model has the capacity to reveal societal preferences in this area which could be helpful in policy formulation related 
to sustainable development. It should be noted that working with a different expert team could lead to some changes in the ranking since the intensity of the influences between the elements of the network reflects the opinion of this group of experts.

Finally, ANP by all means is not free of criticism, it can be very time consuming, somewhat difficult to apply until the logic is understood and relies much on judgements.

\section{References}

Abdalla, K.L. (2005). 'Introduction: Using energy indicators to achieve sustainable development goals' Natural Resources Forum, Vol. 29, No. 4, pp.270-273.

Angelis-Dimakis, A., Arampatzis, G. and Assimacopoulos, D. (2012) 'Monitoring the sustainability of the Greek energy system' Energy for Sustainable Development, Vol. 16, No. 1, pp.51-56.

Ansari, A.K. and Unar, I.N. (2012) 'Sustainable development indicators for energy in Pakistan' in Uqaili, M.A.A. and Harijan, K. (Eds.), Energy, Environment and Sustainable Development, Springer, Wien, pp.25-38.

Atmaca, E. and Basar, H.B. (2012). 'Evaluation of power plants in Turkey using Analytic Network Process (ANP)' Energy, Vol. 44, No. 1, pp.555-563. 
Belton, V. and Stewart T.J. (2002) Multi Criteria Decision Analysis: An Integrated Approach, Kluwer Academic Publishers, Boston.

Bishop, J.D.K. et al. (2008) 'Using strong sustainability to optimize electricity generation fuel mixes' Energy Policy, Vol. 36, No. 3, pp. 971-980.

Bossel, H. (2001) 'Assessing viability and sustainability: a systems-based approach for deriving comprehensive indicator sets' Conservation Ecology, Vol. 5, No. 2 [online] http://www.consecol.org/vol5/iss2/art12/ (Accessed 15 November 2012).

Drexhage, J. and Murphy, D. (2010) Sustainable development: from Brundtland to Rio 2012, United Nations Headquarters, New York.

E.C. (2014a) (Communication from the Commission to the European Parliament, the Council, the European Economic and Social Committee and the Committee of the Regions), A policy framework for climate and energy in the period from 2020 to 2030 [COM(2014)15 final], Brussels.

E.C. (2014b) (Communication from the Commission to the European Parliament, the Council, the European Economic and Social Committee and the Committee of the Regions), Taking stock of the Europe 2020 strategy for smart, sustainable and inclusive growth [COM(2014)130 final/2], Brussels. 
Eurostat (2009) Sustainable development in the European Union: 2009 monitoring report of the EU sustainable development strategy, Brussels.

Eurostat (2012) [online]

http://epp.eurostat.ec.europa.eu/portal/page/portal/energy/data/database (Accessed 15 June 2013).

Eurostat (2014) [online]

http://appsso.eurostat.ec.europa.eu/nui/show.do?dataset=nrg_100a\&lang=en (Accessed 30 July 201443).

Fischer, S. and Geden, O. (2012) 'The EU's energy roadmap 2050: Targets without governance' Stiftung Wissenschaft und Politik, SWP Comments, 2012/C 08.

Giner-Santonja, G., Aragonés-Beltrán, P. and Niclós-Ferragut, J. (2012) 'The application of the analytic network process to the assessment of best available techniques' Journal of Cleaner Production, Vol. 25, pp.86-95.

IAEA, 2005. (International Atomic Energy Agency), UNDESA (United Nations Department of Economic and Social Affairs), IEA (International Energy Agency), Eurostat, EEA (European Environment Agency). Energy indicators for sustainable development: Methodologies and guidelines, IAEA, Vienna.

IPCC (2007) ‘Summary for policymakers’ in Parry, M.L. et al. (Eds), Climate Change 2007: Impacts, Adaptation and Vulnerability, Contribution of Working 
Group II to the Fourth Assessment Report of the Intergovernmental Panel on Climate Change. Cambridge University Press, Cambridge, pp.7-22.

IEA (2006) Energy Balances of OECD Countries 2006, OECD Publishing, Paris.

IEA (2007) Energy Balances of OECD Countries 2007, OECD Publishing, Paris.

IEA (2008a) Electricity Information 2008, OECD Publishing, Paris.

IEA (2008b) Energy Balances of OECD Countries 2008, OECD Publishing, Paris.

IEA (2009a) Electricity Information 2009, OECD Publishing, Paris.

IEA (2009b) Energy Balances of OECD Countries 2009, OECD Publishing, Paris.

IEA (2010a) Electricity Information 2010, OECD Publishing, Paris.

IEA (2010b) Energy Balances of OECD Countries 2010, OECD Publishing, Paris.

IEA, (2011a) Electricity Information 2011, OECD Publishing, Paris.

IEA (2011b) Energy Balances of OECD Countries 2011, OECD Publishing, Paris.

IEA (2011c) World Energy Outlook, OECD Publishing, Paris.

IEA (2012a) Electricity Information 2012, OECD Publishing, Paris. 
IEA (2012b) Energy Balances of OECD Countries 2012, OECD Publishing, Paris.

Ishizaka, A., Labib, A. (2011) 'Selection of new production facilities with the Group Analytic Hierarchy Process Ordering method’ Expert Systems with Applications, Vol. 38, No. 6, pp.7317-7325.

Jovanovic, M. et al. (2011) 'Sustainability estimation of energy system options that use gas and renewable resources for domestic hot water production' Energy, Vol. 36, No. 4, pp.2169-2175.

Köne, A.C., Büke, T. (2007) 'An Analytical Network Process (ANP) evaluation of alternative fuels for electricity generation in Turkey' Energy Policy, 35, No. 10, pp. 5220-5228.

Parris, T.M. and Kates, R.W. (2003) 'Characterizing and measuring sustainable development' Annual Review of Environment and Resources, Vol. 28, pp.559-586.

Rasmussen, L.H. (2003) 'A sustainable energy-system in Latvia’ Applied Energy, Vol. 76, No. 1-3, pp.1-8.

Saaty, T.L. (1996) The analytic network process: Decision-making with dependence and feedback, RWS Publications, Pittsburgh. 
Saaty, T.L. (1999) Creative thinking, problem solving and decision making, RWS Publications, Pittsburgh.

Schlör, H., Fischer, W., Hake, J-F. (2013) 'Methods of measuring sustainable development of the German energy sector' Applied Energy, Vol. 101, pp.172-181.

Smith-Perera, A. et al. (2010) 'A project strategic index proposal for portfolio selection in electrical company based on the Analytic Network Process' Renewable and Sustainable Energy Reviews, Vol. 14, No. 6, pp.1569-1579.

UN (1992) Agenda 21, Proceedings of the United Nations Conference on Environment and Development. Rio de Janeiro, Brazil, 3-14 June 1992. United Nations. [online] http://www.un.org/esa/sustdev/documents/agenda21/english/Agenda21.pdf (Accessed 8 June 2012).

World Bank (2012) World Development Indicators, 2000-2010 [online] http://data.worldbank.org/indicator (Accessed 15 July 2012)

WCED (1987) (World Commission on Environment and Development), Our common future, Oxford University Press, Oxford.

WEC (2011) Policies for the future: 2011 assessment of country energy and climate policies World Energy Council, London. 
Wolfslehner, B., Vacik, H. (2008) 'Evaluating sustainable forest management strategies with the Analytic Network Process in a Pressure-State-Response framework' Journal of Environmental Management, Vol. 88, No. 1, pp. 1-10.

Xiaodan, W. et al. (2010) 'A GIS based decision support system for regional ecosecurity assessment and its application on the Tibetan Plateau' Environmental Management, Vol. 91, No. 10, pp. 1981-1990.

Xu, P. and Chan E.H.W. (2013) 'ANP model for sustainable Building Energy Efficiency Retrofit (BEER) using Energy Performance Contracting (EPC) for hotel buildings in China' Habitat International. Vol. 37, pp. 104-112. 
Table 1

\section{Criteria selection}

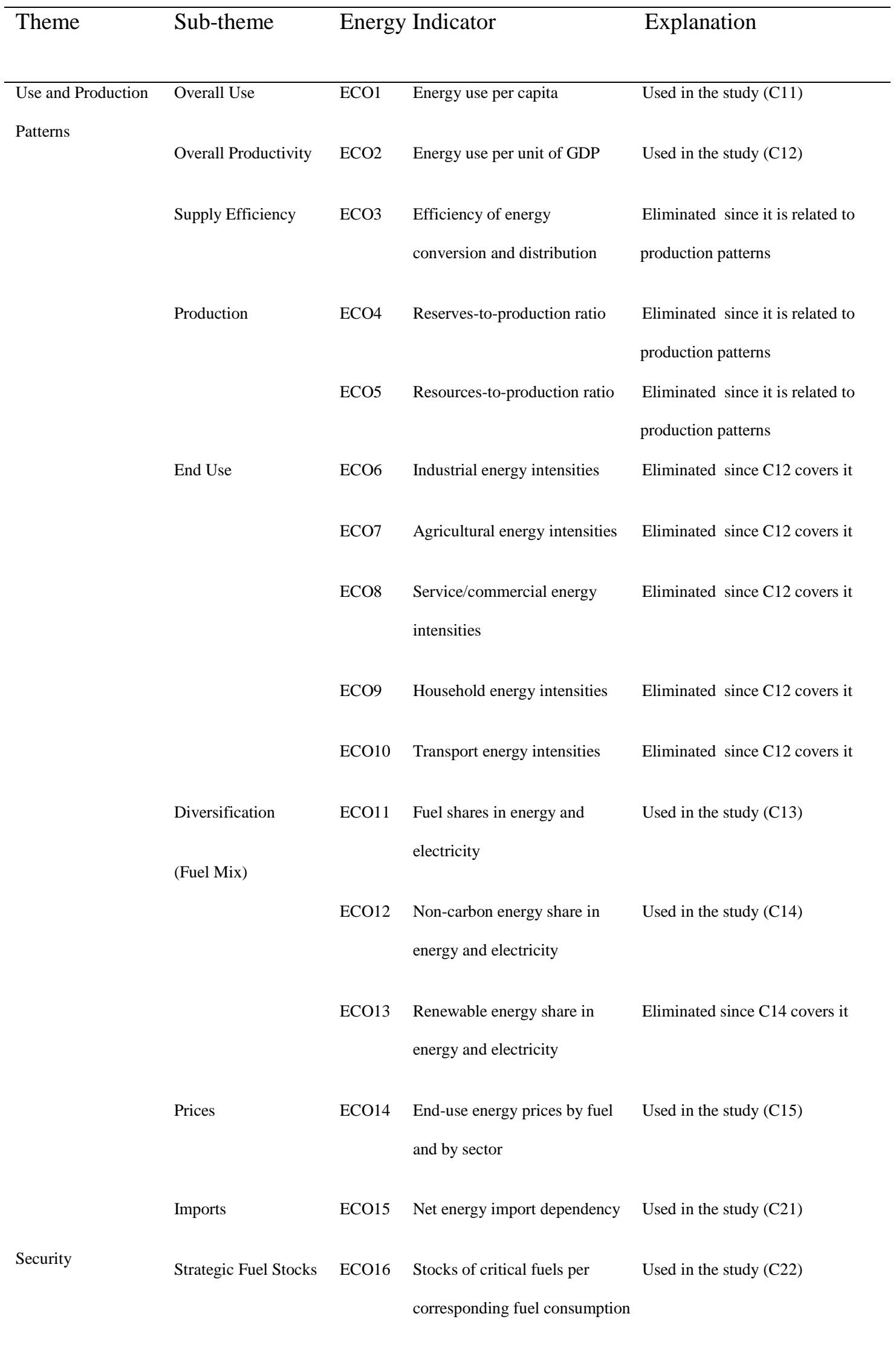


Table 2

Interfactorial dominance matrix

\begin{tabular}{|c|c|c|c|c|c|c|c|c|c|c|c|c|c|c|}
\hline & & \multicolumn{6}{|c|}{ Alternatives } & \multicolumn{5}{|l|}{$\mathrm{C} 1$} & \multicolumn{2}{|l|}{$\mathrm{C} 2$} \\
\hline & & $\mathrm{A} 1$ & $\mathrm{~A} 2$ & $\mathrm{~A} 3$ & A4 & A5 & A6 & C11 & $\mathrm{C} 12$ & $\mathrm{C} 13$ & C14 & $\mathrm{C} 15$ & $\mathrm{C} 21$ & $\mathrm{C} 22$ \\
\hline \multirow[t]{6}{*}{ Alternatives } & A1 & 0 & 0 & 0 & 0 & 0 & 0 & 1 & 1 & 1 & 1 & 1 & 1 & 1 \\
\hline & $\mathrm{A} 2$ & 0 & 0 & 0 & 0 & 0 & 0 & 1 & 1 & 1 & 1 & 1 & 1 & 1 \\
\hline & A3 & 0 & 0 & 0 & 0 & 0 & 0 & 1 & 1 & 1 & 1 & 1 & 1 & 1 \\
\hline & A4 & 0 & 0 & 0 & 0 & 0 & 0 & 1 & 1 & 1 & 1 & 1 & 1 & 1 \\
\hline & A5 & 0 & 0 & 0 & 0 & 0 & 0 & 1 & 1 & 1 & 1 & 1 & 1 & 1 \\
\hline & A6 & 0 & 0 & 0 & 0 & 0 & 0 & 1 & 1 & 1 & 1 & 1 & 1 & 1 \\
\hline \multirow[t]{5}{*}{$\mathrm{C} 1$} & $\mathrm{C} 11$ & 1 & 1 & 1 & 1 & 1 & 1 & 1 & 1 & 1 & 1 & 1 & 1 & 1 \\
\hline & $\mathrm{C} 12$ & 1 & 1 & 1 & 1 & 1 & 1 & 1 & 1 & 0 & 0 & 1 & 0 & 0 \\
\hline & $\mathrm{C} 13$ & 1 & 1 & 1 & 1 & 1 & 1 & 0 & 0 & 1 & 1 & 1 & 0 & 1 \\
\hline & $\mathrm{C} 14$ & 1 & 1 & 1 & 1 & 1 & 1 & 0 & 0 & 0 & 1 & 1 & 0 & 1 \\
\hline & $\mathrm{C} 15$ & 1 & 1 & 1 & 1 & 1 & 1 & 1 & 0 & 0 & 0 & 1 & 0 & 1 \\
\hline \multirow[t]{2}{*}{$\mathrm{C} 2$} & $\mathrm{C} 21$ & 1 & 1 & 1 & 1 & 1 & 1 & 1 & 0 & 1 & 0 & 0 & 1 & 1 \\
\hline & $\mathrm{C} 22$ & 1 & 1 & 1 & 1 & 1 & 1 & 0 & 0 & 1 & 0 & 0 & 0 & 1 \\
\hline
\end{tabular}


Table 3

Sample questionnaire about prioritisation of clusters

Compare the following groups that have some influence upon the A: Alternatives

\section{C1: Use Patterns}

\section{C2: Security}

Which has the greatest

C1

$\mathrm{C} 2$

influence?

$\circ$

$\circ$

To what extent?

\begin{tabular}{|c|c|c|c|}
\hline Equally & Moderately & Important & Very \\
\hline
\end{tabular}

○

○

$\circ$

○

$\bigcirc$ 
Table 4

Pairwise comparison of clusters by experts

Expert-1 Expert-2 Expert-3 Expert-4 Expert-5 GM ${ }^{\mathrm{a}}$

Influence upon the $\mathrm{C} 1$

$\begin{array}{lllllll}\text { C1 }\left(\begin{array}{lll}9 & 1 & 9\end{array}\right) \mathrm{C} 2 & 1 / 3 & 5 & 1 / 7 & 5 & 1 / 5 & 0.75 \\ \mathrm{C} 1\left(\begin{array}{lll}9 & 1 & 9\end{array}\right) \mathrm{A} & 1 & 1 & 1 & 1 & 1 & 1.00 \\ \mathrm{C} 2\left(\begin{array}{lll}9 & 1 & 9\end{array}\right) \mathrm{A} & 1 & 1 & 1 & 1 & 1 & 1.00\end{array}$

Influence upon the C2

$\begin{array}{lllllll}\mathrm{C} 1\left(\begin{array}{ll}9 & 19\end{array}\right) \mathrm{C} 2 & 1 / 3 & 5 & 1 / 3 & 1 / 5 & 1 / 5 & 0.47\end{array}$

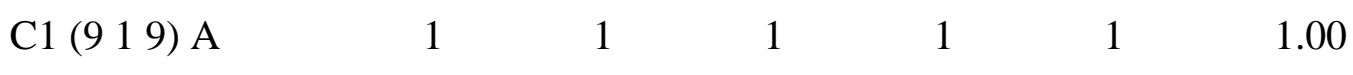

$\begin{array}{lllllll}\mathrm{C} 2\left(\begin{array}{lll}9 & 1 & 9\end{array}\right) \mathrm{A} & 1 & 1 & 1 & 1 & 1 & 1.00\end{array}$

Influence upon the A

$\begin{array}{lllllll}\mathrm{C} 1\left(\begin{array}{l}9 \\ 9\end{array} \text { 9) } \mathrm{C} 2\right. & 1 / 3 & 5 & 1 / 7 & 1 / 9 & 3 & 0.60\end{array}$

${ }^{\mathrm{a}} \mathrm{GM}$ : Geometric Mean 
Table 5

Pairwise comparison of criteria by experts

\begin{tabular}{|c|c|c|c|c|c|c|c|}
\hline & & Expert-1 & Expert-2 & Expert-3 & Expert-4 & Expert-5 & $\mathrm{GM}^{\mathrm{a}}$ \\
\hline \multicolumn{8}{|c|}{ Influence upon the $\mathrm{C} 11$} \\
\hline C11 (9 1 9) C12 & & 1 & 1 & $1 / 3$ & 1 & 1 & 0.80 \\
\hline C11 (9 19$)$ C15 & & $1 / 3$ & $1 / 5$ & $1 / 3$ & 3 & $1 / 3$ & 0.47 \\
\hline C12 (9 1 9) C15 & & $1 / 3$ & $1 / 3$ & $1 / 3$ & 7 & $1 / 3$ & 0.61 \\
\hline \multicolumn{8}{|c|}{ Influence upon the $\mathrm{C} 12$} \\
\hline C11 (9 1 9) C12 & & 3 & $1 / 5$ & $1 / 5$ & 3 & $1 / 3$ & 0.65 \\
\hline \multicolumn{8}{|c|}{ Influence upon the $\mathrm{C} 13$} \\
\hline C11 (9 1 9) C13 & & 3 & 3 & 3 & 1 & 1 & 1.93 \\
\hline C21 (9 1 9) C22 & & $1 / 3$ & 3 & 1 & $1 / 5$ & 1 & 0.72 \\
\hline \multicolumn{8}{|c|}{ Influence upon the $\mathrm{C} 14$} \\
\hline C11 (9 1 9) C13 & & 3 & 3 & 3 & 5 & 3 & 3.32 \\
\hline C11 (9 1 9) C14 & & $1 / 3$ & 3 & $1 / 7$ & $1 / 5$ & $1 / 5$ & 0.36 \\
\hline C13 (9 1 9) C14 & & $1 / 5$ & $1 / 3$ & $1 / 7$ & $1 / 3$ & $1 / 5$ & 0.23 \\
\hline \multicolumn{8}{|c|}{ Influence upon the $\mathrm{C} 15$} \\
\hline C11 (9 1 9) C12 & & 3 & $1 / 5$ & $1 / 3$ & $1 / 5$ & 1 & 0.53 \\
\hline C11 (9 1 9) C13 & & 3 & 3 & 1 & $1 / 3$ & 3 & 1.55 \\
\hline C11 (9 1 9) C14 & & $1 / 3$ & 3 & $1 / 5$ & $1 / 5$ & 1 & 0.53 \\
\hline C11 (9 1 9) C15 & & $1 / 3$ & $1 / 7$ & $1 / 5$ & 3 & $1 / 3$ & 0.39 \\
\hline C12 (9 1 9) C13 & & 1 & 5 & 3 & $1 / 3$ & 3 & 1.72 \\
\hline C12 (9 1 9) C14 & & $1 / 3$ & 7 & $1 / 5$ & $1 / 5$ & $1 / 5$ & 0.45 \\
\hline C12 (9 1 9) C15 & & $1 / 3$ & 1 & $1 / 7$ & 5 & 1 & 0.75 \\
\hline C13 (9 1 9) C14 & & $1 / 3$ & 1 & 5 & $1 / 5$ & $1 / 3$ & 0.64 \\
\hline C13 (9 1 9) C15 & & $1 / 3$ & $1 / 7$ & $1 / 3$ & 3 & $1 / 3$ & 0.44 \\
\hline C14 (9 1 9) C15 & & 3 & $1 / 7$ & 1 & 5 & 3 & 1.45 \\
\hline \multicolumn{8}{|c|}{ Influence upon the $\mathrm{C} 22$} \\
\hline C11 (9 19) C13 & & 3 & 3 & 1 & 5 & 3 & 2.67 \\
\hline C11 (9 1 9) C14 & & $1 / 3$ & 3 & $1 / 3$ & 5 & $1 / 3$ & 0.89 \\
\hline C11 (9 1 9) C15 & & 3 & $1 / 7$ & $1 / 3$ & 3 & 3 & 1.05 \\
\hline C13 (9 1 9) C14 & & $1 / 3$ & $1 / 3$ & $1 / 7$ & $1 / 5$ & $1 / 3$ & 0.25 \\
\hline C13 (9 1 9) C15 & & $1 / 3$ & $1 / 7$ & $1 / 7$ & $1 / 5$ & $1 / 3$ & 0.21 \\
\hline C14 (9 1 9) C15 & & 3 & $1 / 7$ & 3 & 3 & 3 & 1.63 \\
\hline $\mathrm{C} 21(919) \mathrm{C} 22$ & & 1 & 3 & $1 / 7$ & $1 / 3$ & 1 & 0.68 \\
\hline
\end{tabular}


Table 6

Quantitative data used for the comparisons of the alternatives (average values for the period 2000-2010)

\begin{tabular}{lllllll}
\hline Alternative/criteria & A1 & A2 & A3 & A4 & A5 & A6 \\
& & & & & & \\
\hline C11 (toe/capita) & 4.24 & 4.12 & 3.02 & 3.13 & 1.24 & 3.65 \\
C12 (toe/thousand 2000 USD) & 0.1597 & 0.1541 & 0.1164 & 0.1367 & 0.1434 & 0.1320 \\
C13 (\%) & 51.95 & 81.77 & 90.31 & 81.05 & 88.14 & 88.42 \\
C14 (\%) & & & & & & \\
C15 (USD/kWh) & 45.14 & 13.60 & 4.91 & 15.25 & 5.35 & 9.53 \\
C21 (\%) & 0.126 & 0.206 & 0.214 & 0.185 & 0.222 & 0.142 \\
C22 (\%) & & & & & & \\
& 50.85 & 60.38 & 84.80 & 78.51 & 70.12 & 8.63 \\
& & & & & & \\
\hline
\end{tabular}


Table 7

Weighted super matrix

\begin{tabular}{|c|c|c|c|c|c|c|c|c|c|c|c|c|c|c|}
\hline & & \multicolumn{6}{|l|}{ A } & \multicolumn{5}{|l|}{$\mathrm{C} 1$} & \multicolumn{2}{|l|}{$\mathrm{C} 2$} \\
\hline & & A1 & A2 & A3 & A4 & A5 & A6 & C11 & $\mathrm{C} 12$ & C13 & C14 & C15 & C21 & $\mathrm{C} 22$ \\
\hline \multirow[t]{6}{*}{ A } & A1 & 0.00000 & 0.00000 & 0.00000 & 0.00000 & 0.00000 & 0.00000 & 0.03560 & 0.07247 & 0.08301 & 0.24067 & 0.11520 & 0.03378 & 0.06480 \\
\hline & A2 & 0.00000 & 0.00000 & 0.00000 & 0.00000 & 0.00000 & 0.00000 & 0.03663 & 0.07511 & 0.05247 & 0.07251 & 0.07046 & 0.02846 & 0.05047 \\
\hline & $\mathrm{A} 3$ & 0.00000 & 0.00000 & 0.00000 & 0.00000 & 0.00000 & 0.00000 & 0.04997 & 0.09944 & 0.04774 & 0.02618 & 0.06797 & 0.02023 & 0.01993 \\
\hline & A4 & 0.00000 & 0.00000 & 0.00000 & 0.00000 & 0.00000 & 0.00000 & 0.04825 & 0.08463 & 0.05290 & 0.08131 & 0.07865 & 0.02177 & 0.03009 \\
\hline & A5 & 0.00000 & 0.00000 & 0.00000 & 0.00000 & 0.00000 & 0.00000 & 0.12150 & 0.08070 & 0.04860 & 0.02852 & 0.06525 & 0.02452 & 0.04113 \\
\hline & A6 & 0.00000 & 0.00000 & 0.00000 & 0.00000 & 0.00000 & 0.00000 & 0.04138 & 0.08765 & 0.04860 & 0.05081 & 0.10248 & 0.19872 & 0.12107 \\
\hline \multirow[t]{5}{*}{$\mathrm{C} 1$} & $\mathrm{C} 11$ & 0.05570 & 0.02867 & 0.03264 & 0.03985 & 0.03387 & 0.03904 & 0.08333 & 0.16667 & 0.22222 & 0.13418 & 0.06411 & 0.25992 & 0.07312 \\
\hline & $\mathrm{C} 12$ & 0.06461 & 0.05314 & 0.04320 & 0.04751 & 0.04664 & 0.04769 & 0.08333 & 0.33333 & 0.00000 & 0.00000 & 0.10604 & 0.00000 & 0.00000 \\
\hline & $\mathrm{C} 13$ & 0.03549 & 0.03143 & 0.02631 & 0.03004 & 0.02261 & 0.02804 & 0.00000 & 0.00000 & 0.11111 & 0.05861 & 0.05279 & 0.00000 & 0.02012 \\
\hline & C14 & 0.08341 & 0.12510 & 0.14752 & 0.11907 & 0.14668 & 0.13954 & 0.00000 & 0.00000 & 0.00000 & 0.30721 & 0.12341 & 0.00000 & 0.09538 \\
\hline & $\mathrm{C} 15$ & 0.09413 & 0.09500 & 0.08367 & 0.09687 & 0.08352 & 0.07902 & 0.16667 & 0.00000 & 0.00000 & 0.00000 & 0.15365 & 0.00000 & 0.07130 \\
\hline \multirow[t]{2}{*}{$\mathrm{C} 2$} & $\mathrm{C} 21$ & 0.44444 & 0.50000 & 0.53333 & 0.53333 & 0.53333 & 0.33333 & 0.33333 & 0.00000 & 0.16667 & 0.00000 & 0.00000 & 0.41260 & 0.13753 \\
\hline & $\mathrm{C} 22$ & 0.22222 & 0.16667 & 0.13333 & 0.13333 & 0.13333 & 0.33333 & 0.00000 & 0.00000 & 0.16667 & 0.00000 & 0.00000 & 0.00000 & 0.27507 \\
\hline
\end{tabular}


Table 8

Averaged cluster weights from the experts' pairwise comparison

\begin{tabular}{llll}
\hline Clusters & Alternatives & C1 & C2 \\
\hline Alternatives & 0.000000 & 0.333333 & 0.322780 \\
C1 & 0.333333 & 0.333333 & 0.259921 \\
C2 & 0.666667 & 0.333333 & 0.412599 \\
\hline
\end{tabular}




\section{Figure Caption}

Fig. 1. EISD indicators

Fig. 2. General ANP-based methodology

Fig. 3. ANP model for comprehensive evaluation.

Fig. 4. The weights of the criteria in the ANP model

Fig. 5. Priorities of the alternatives with respect to the each cluster

Fig. 6. Priorities of the alternatives for the ANP model 
"Fig.1."

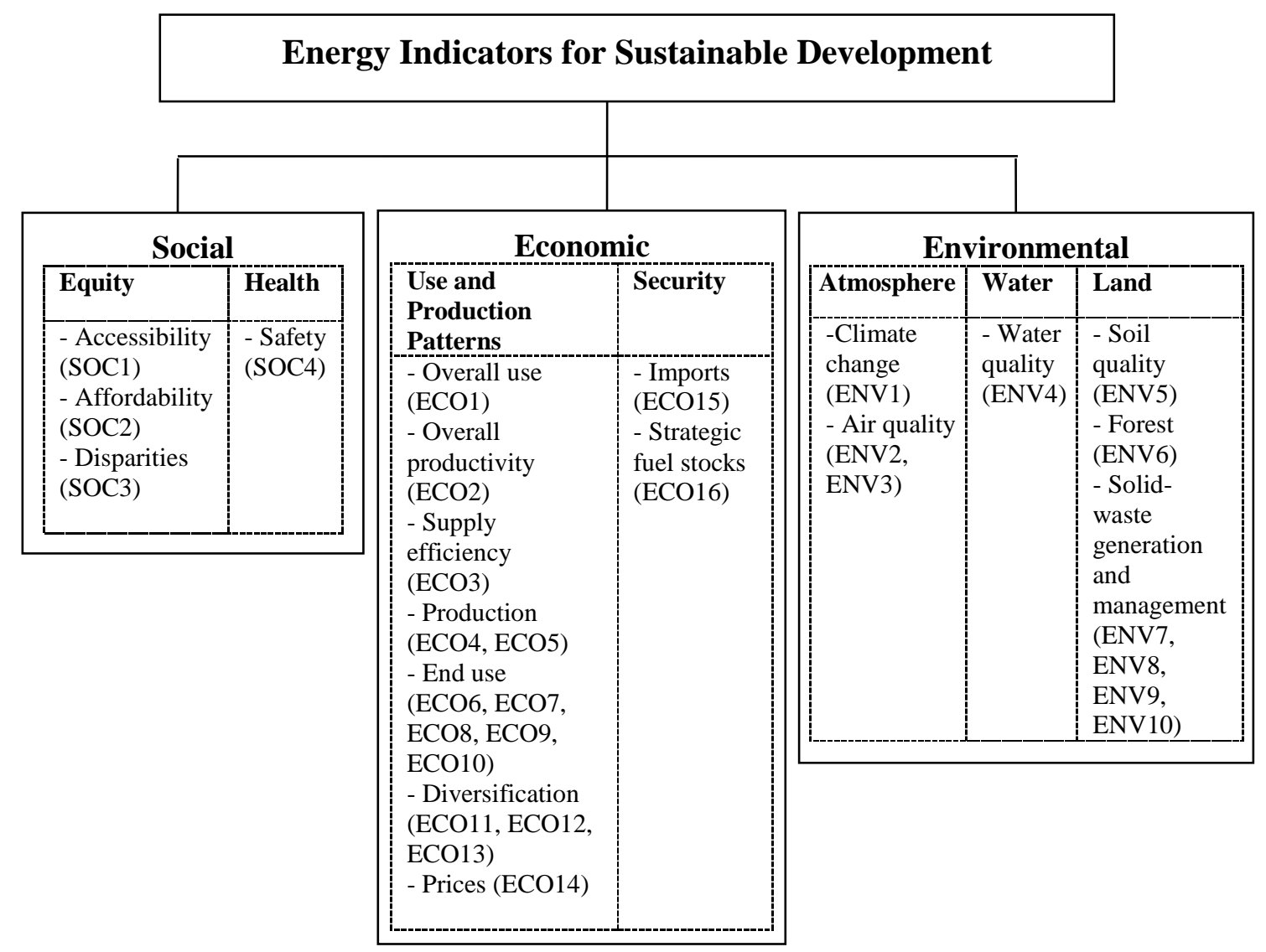


"Fig.2."

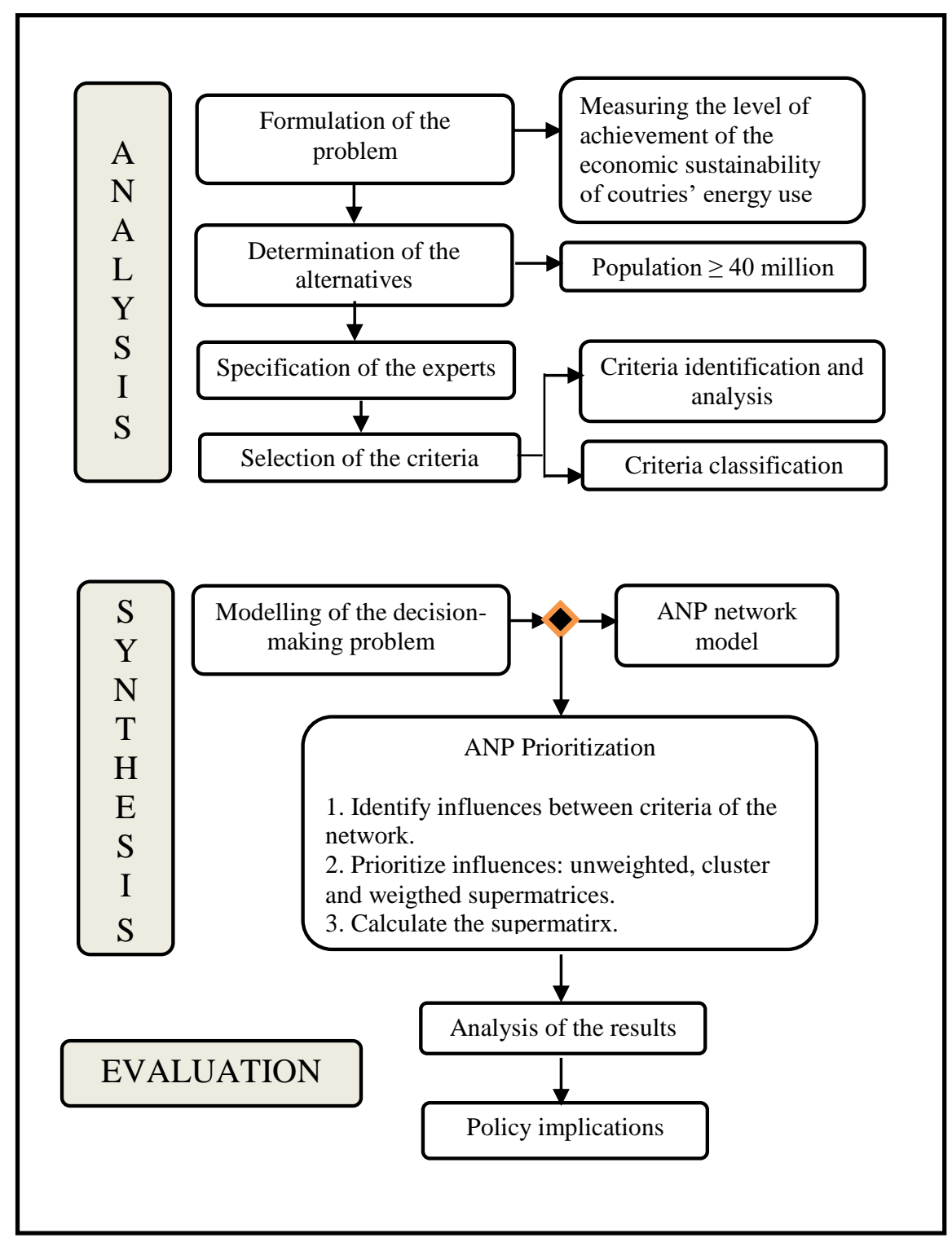


"Fig.3."

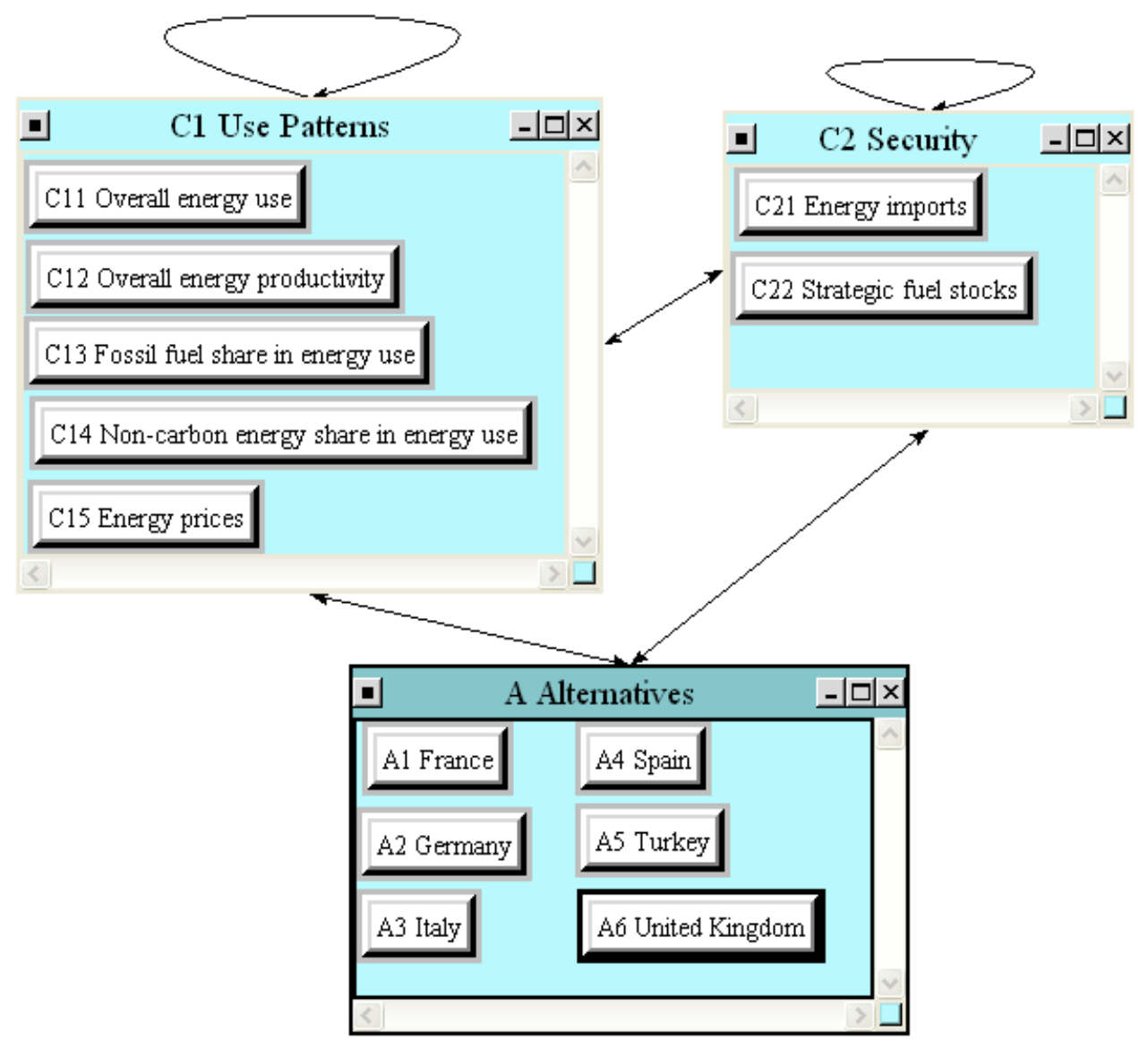


"Fig.4."

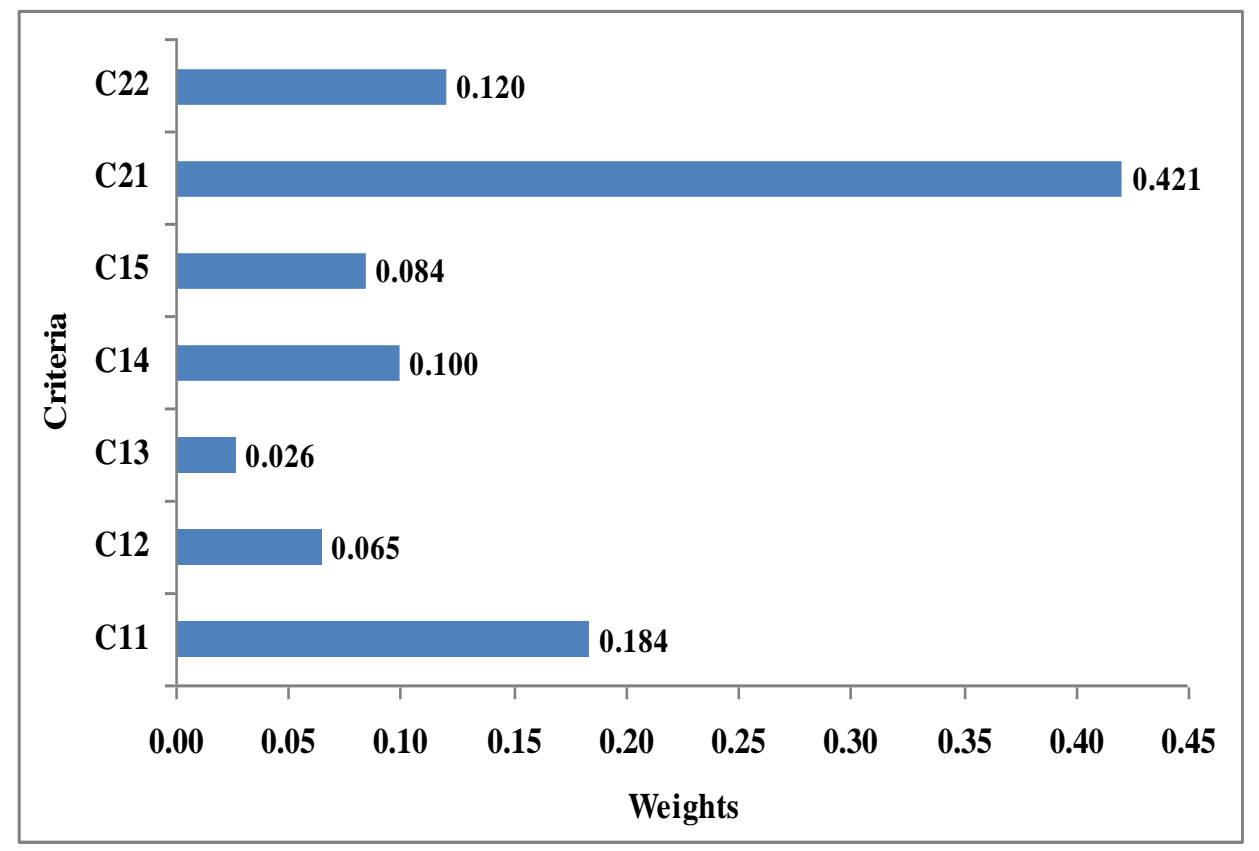


"Fig.5."

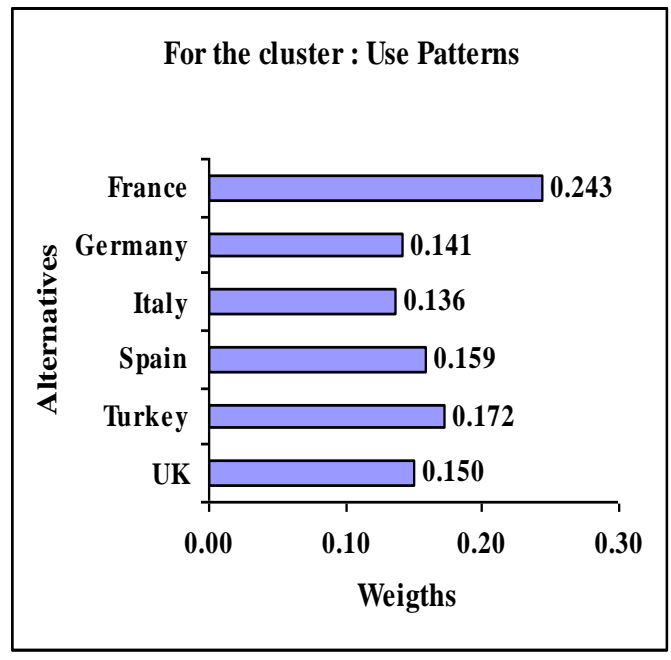

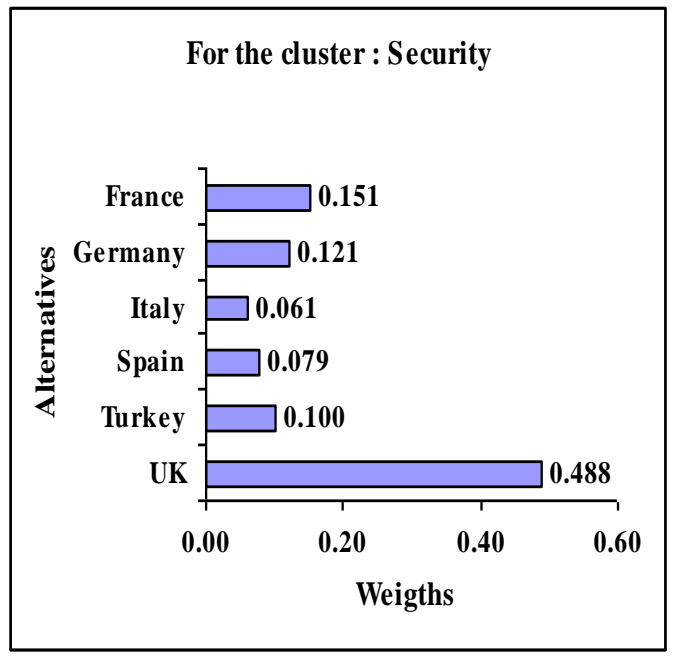


"Fig.6."

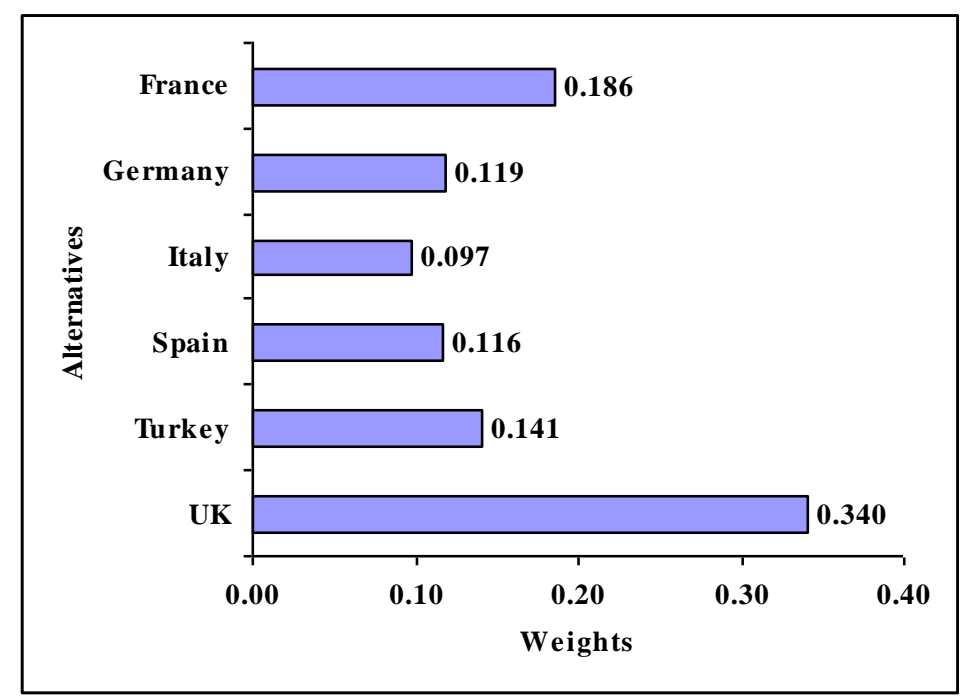

